\title{
STUDENTS' PERCEPTIONS TOWARD GRAMMAR IN ENGLISH CLASSROOM
}

\author{
Mirna Nur Mirazna1, Nur Hikmah² \\ ${ }^{1}$ IKIP Siliwangi \\ ${ }^{2}$ IKIP Siliwangi \\ ${ }^{1}$ mirnanm834@gmail.com, ${ }^{2}$ nunuyhikmah65@gmail.com
}

\begin{abstract}
The objective of this research focuses on students perceptions toward grammar in the English classroom. This research uses the qualitative descriptive method, the procedure for collecting data uses questionnaire analysis in google forms free online questionnaire. The population is 30 students in class TEI C at SMK TI Pembangunan Cimahi. The sample is 30 students. The results of the data analysis showed that $60 \%$ of students stongly agree that grammar in the English classroom important, while the other $40 \%$ agree. In addition $96 \%$ of students admit that their need to increase English grammar. The most dominant of students perceptions grammar showed to increase skills on grammar $96 \%$ of students choose to agree on statements. The findings revealed that students perceived differently toward grammar in the English classroom.
\end{abstract}

Keywords: Students Perceptions, Grammar, English

\section{INTRODUCTION}

English as an international language is use by people all over the world. As stated by Mundriyah and Parmawati (2016) that English is used in many activities either orally or in writen form. Grammar is an important part of learning English. Since first learning English has been exposed to grammar. Students have faced grammar since being in school and even at university. According to Al-Mekhlafi \& Nagaratman in Sani (2016), there are three areas of grammar, which are grammar as rules, grammar as form, and grammar as resource. They added that many students think that learning grammar means learning the rules of grammar and having intellectual knowledge about grammar. People have different perceptions about the roles of grammar. Some have positive perceptions and some have negative perceptions.

Grammar very important and may affect one's success in English. Grammar has a big roles in the teaching of English as a foreign language. Besides that, grammar is one of the factors that determine students' success in study English. Al-Mekhlafi \& Nagaratnaam in Sani (2016), grammar is a valuable aspect for oral or written communication. In addition, both students and teachers assume that grammar study is not sufficient, whereas for the real-life communication grammar is also important.

Although grammar is important, there are many types of difficulties faced by students on the effect of grammar instruction in the ESL/EFL context. Haudeck in Sani (2016), many learners have difficulty in internalizing grammar rules, although these have been taught intensively. Most of the classes mention grammar causes moments during discomfort and sometimes even 
terror. The definition of grammar is the learning of how words and component parts combine to sentences. People sometimes describe grammar as the "rules" of a language. Al-Mekhlafi \& Nagaratman in Sani (2016) said that in teaching grammar three areas have to be considered: grammar as rules, grammar as form, and grammar as resource. In another words grammar has some grammatical parts for example words, sentences, paragraphs, nouns, verbs, and punctuation.

Perceptions refers to the ability to choose something through the senses such as smelling, hearing, seeing and touching. According to Lindsay \& Norman (1973), perceptions is the process by which organisms interpret and regulate sensations to produce a meaningful world experiences, in other words perceptions is the way people think and respect something. This might be different from one another because people sometimes have different thoughts even though they think the same thing. Perceptions can also be described as the way people notice or understand something using one of their feelings.

Perceptions is the process of interpreting and recognizing sensory stimulation. Perceptions also include how to respond to the information, information something meaningful. According to Vygotsky in Sodik \& Wijaya (2017), perception is a dynamic system of behaviour which is always changing. Besides that, according to Ronald (2008), perception is an important process that covers the selection, organization, and interpretation of sensory data which help other people define their world and influence their behaviour.

Based on the explanation that this study aims to investigate students perceptions toward grammar in English classroom, beside that this research focuses on about perceptions students grammar at SMK TI Pembangunan Cimahi.

\section{METHOD}

This research uses qualitative descriptive method. The qualitative descriptive method have become a very common procedure for conducting research including education, the purpose of descriptive research is to describe a characteristics and phenomenon. Creswell in Nassaji (2015), qualitative descriptive data as a whole to find relevant themes and ideas and then convert them to numerical data for further comparison and evaluation. The procedure used to collect the data researchers uses questionnaire analysis in google forms the free online questionnaire. In this research, the researchers took SMK TI Pembangunan Cimahi students, the population of the research is 30 students in class X TEI C and the sample is 15 while population. The data collected was analyze to explore there attitude, behavior, and experience which emerged along teaching program (Dawson, 2009, cited in Apsari and Yana, 2015)

\section{RESULTS AND DISCUSSION}

\section{Results}

This research used a questionnaire to collect the data to determine students' perceptions of grammar. Because the researchers used questionnaires there are some statements given with a scale such as strongly agree, agree, disagree, and strongly disagree. Questionnaires are 
presented in Indonesian to make it easier participants to understand the statement. This section discusses the findings from the analysis of the data, the data obtained from questionnaire were analyzed to answer the research question "what are the students' perceptions toward grammar at SMK TI Pembangunan Cimahi ?" In this part, the researchers discussed the finding of the closed-ended questionnaire in which students rated each statement according to four-point scale by putting a check mark on the appropriate column: strongly agree, agree, disagree, and strongly disagree. The researchers categorized 14 questions. Presented below, are the mean and percentages of the participants' responses and their discussion.

\section{Results}

\begin{tabular}{lcccccc}
\hline No & \multicolumn{1}{c}{ Questions } & SA & A & D & SD & TOTAL \\
\hline 1. & $\begin{array}{l}\text { I think learning grammar is important } \\
\text { in the context of studying English }\end{array}$ & $40 \%$ & $60 \%$ & $0 \%$ & $0 \%$ & $100 \%$ \\
2. $\quad \begin{array}{l}\text { I think learning grammar can help } \\
\text { me to communicate in English } \\
\text { well. }\end{array}$ & $60 \%$ & $40 \%$ & $0 \%$ & $0 \%$ & $100 \%$ \\
& & & & &
\end{tabular}

3. I can feel that I get more benefits and $\quad \begin{array}{llllll}30 \% & 60 \% & 10 \% & 0 \% & 100 \%\end{array}$ knowledge when I learn English at school

4. I think by learning grammar I can $\quad 20 \% \quad 70 \% \quad 10 \% \quad 0 \% \quad 100 \%$ measure my ability in learning English well.

5. I think that learning grammar can $\quad 30 \% \quad 60 \% \quad 0 \% \quad 10 \% \quad 100 \%$ help me to be successful in acquiring English.

6. I think I need to increase my skills on $\quad 0 \% \quad 96 \% \quad 0 \% \quad 4 \% \quad 100 \%$ grammar.

7. I feel that learning grammar is wasting time

8. I think grammar is an interesting subject to learn at school

9. I like learning grammar

$5 \% \quad 5 \% \quad 70 \% \quad 20 \% \quad 100 \%$

10. I think learning grammar is easy.

$20 \% \quad 60 \% \quad 20 \% \quad 0 \% \quad 100 \%$

$\begin{array}{lllll}10 \% & 70 \% & 10 \% & 10 \% & 100 \%\end{array}$

$\begin{array}{lllll}10 \% & 50 \% & 30 \% & 10 \% & 100 \%\end{array}$

11. I think learning grammar is fun.

$20 \% \quad 60 \% \quad 20 \% \quad 0 \% \quad 100 \%$

12. I feel learning grammar is difficult.

$20 \% \quad 30 \% \quad 50 \% \quad 0 \% \quad 100 \%$

13. I feel that learning grammar is very

$20 \% \quad 70 \% \quad 10 \% \quad 0 \% \quad 100 \%$ boring.

14. Can you follow grammar lesson in the classroom very easily 


\section{Discussion}

Based on the research from the questions above, there are several of positive questions and negative questions. The positive question there are, learning grammar is important in the context of studying English, from this question many students choose to agree. Learning grammar can help to communicative in English well, from this question many students choose to strongly agree. Grammar is an interesting subject to learn at school, from this question many students choose to agree.

The negative questions there are, learning grammar is wasting time, from this question many students choose to disagree. Learning grammar is difficult, from this question many students choose to disagree. Learning grammar is very boring, from this question many students choose to agree. Based on the questions that this statement is supported by Sani (2016). which states that learning grammar is wasting time because it makes a students have to think hard, besides that learning grammar is very boring because students feel learning about grammar sometimes doesn't understand.

From the results show that students perceptions is different. Students consider that grammar is important and anyone considers that grammar is not important, but grammar is the factors students' success in learning English. Harmer in Sodik \& Wijaya (2017), grammar as the description of the ways in which words can change their forms and can be combine into sentences in the language. In addition, according to Gerot and Wignell in Setiyaningsih (2013), grammar is a theory of a language, of how language is put together and how it works. Therefore, grammar is the key to successful communication.

\section{CONCLUSION}

The research was conducted to find out students' perceptions toward grammar at SMK TI Pembangunan Cimahi. After collecting data, from the part the researchers found out that the students were aware of the importance of grammar. The revealed data that students need to learn grammar in context of studying English. The students assumed that by learning grammar they can measure their English learning abilities because they may get more useful and knowledge to be used while they were communicating in English. Students also think that they can gain their English skills by learning grammar and they feel that their need to learn more about it. They assumed that learning grammar is useful and not wasting their time in learning. The study found that students were interested in learning grammar. They feel that the grammar lesson system is easily understood and they can follow the teaching and learning process well.

\section{ACKNOWLEDGMENTS}

Alhamdulillah all gratitude to Allah S.W.T who gave His blessing to researchers, so researchers can finish this article with good health condition. The researchers would like to say the biggest thank you for the lecturer who always gave the researchers support when conducting this research. Also, researchers would like to say thank you to SMK TI Pembangunan Cimahi, class 
A2 Regular 2015 English Education Study Program, and my family always support the researchers when the researchers conducting this research, also IKIP Siliwangi Bandung which gave us opportunity to publish this article. The researchers hope this research can be published and seen by many people.

\section{REFERENCES}

Abdu, M. A.-M., \& Ramani, P. N. (2011). Difficulties in Teaching and Learning Grammmar in an EFL Context. International Journal of Instruction, 4(2), 69-92.

Apsari, Y., \& Yana, Y. (2015). Teachers'techniques And Problems In Teaching Reading. P2m Stkip Siliwangi, 2(2), 217-233.

Lindsay. h Peter, \& Norman Donald A. (1973). An Introduction to Psychology.

Nassaji, H. (2015). Qualitative and descriptive research: Data type versus data analysis. Language Teaching Research, 19(2), 129-132. https://doi.org/10.1177/1362168815572747

Mundriyah, M., \& Parmawati, A. (2016). Using Think-Pair-Share (Tps) To Improve Students'writing Creativity (A Classroom Action Research In The Second Semester Students Of Stkip Siliwangi Bandung). P2m Stkip Siliwangi, 3(2), 84-91.

Ronald, A. B. (2008). Business Law E-Commerce.

Sani, H. K. (2016). Senior High School Students' Perceptions Towards Grammar English Language Education Program Faculty of Language and Arts Universitas Kristen Satya Wacana $2016 . \quad$ Retrieved from http://repository.uksw.edu/bitstream/123456789/9438/2/T1_112011087_Full text.pdf

Setiyaningsih, A. (2013). the Use of Problem Based Learning To Improve Students '. Journal of English Language Teaching, 2(2), 1-8.

Sodik, F., \& Wijaya, M. S. (2017). Implementing Scientific Approach of 2013 Curriculum at KTSP-Based School for Teaching Present Continuous Tense. English Ediucation: Jurnal Tadris Bahasa Inggris, 10(1), 16-28. 